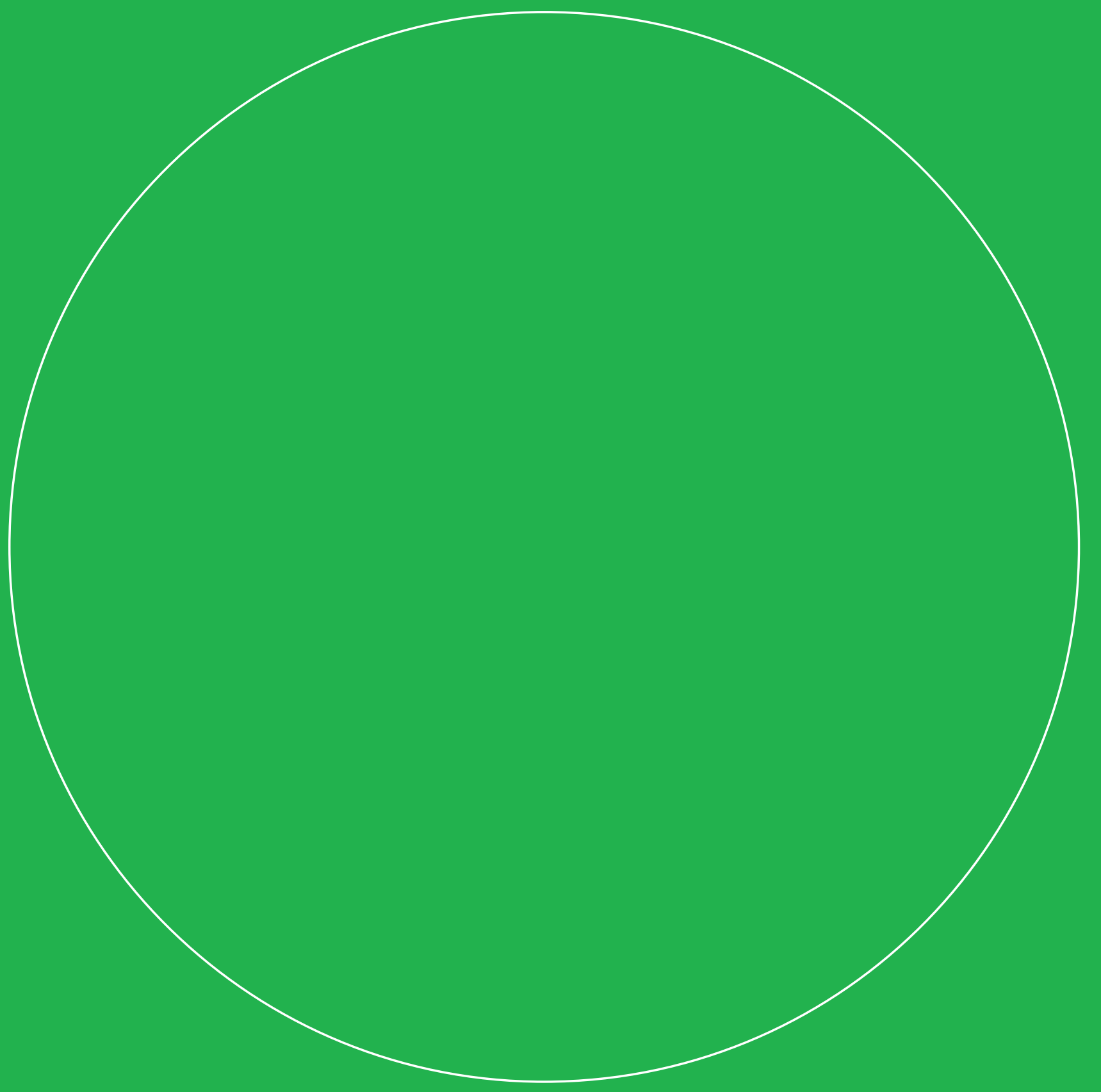

New Application of Brewers Spent Grain for Food 



\section{New Application of Brewers Spent Grain for Food}

Authors: Henk van Deventer, Juliën Voogt, Jan Broeze, Theo Verkleij

This research project has been carried out by Wageningen Food \& Biobased Research (project number 6234162601). 
Version: final

Confidential until: February 2022

Reviewer: Sanne Stroosnijder

Approved by: Ben Langelaan

Sponsor: Stichting Samen Tegen Voedselverspilling

(C) 2020 Wageningen Food \& Biobased Research, institute within the legal entity Stichting Wageningen Research.

Confidential report. Nothing from this publication may be reproduced and/or made public without prior written permission by the director of Wageningen Food \& Biobased Research.

This report can be downloaded for free from February 2022 at https://doi.org/10.18174/529917.

PO box 17, 6700 AA Wageningen, The Netherlands, T + 31 (0)317 4800 84, E info.wfbr@wur.nl, www.wur.eu/wfbr. Wageningen Food \& Biobased Research is part of Wageningen University \& Research.

All rights reserved. No part of this publication may be reproduced, stored in a retrieval system of any nature, or transmitted, in any form or by any means, electronic, mechanical, photocopying, recording or otherwise, without the prior permission of the publisher. The publisher does not accept any liability for inaccuracies in this report. 


\section{Contents}

$\begin{array}{ll}\text { Summary } & 4\end{array}$

1 Introduction $\quad 5$

2 Drying $\quad 6$

2.1 Overview of dryers $\quad 6$

2.1.1 The Andritz paddle dryer

2.1.2 Alternative dryers 6

$\begin{array}{lll}2.2 & \text { Drying as part of a process line } & 7\end{array}$

$3 \quad$ Experiments with a paddle dryer $\quad 9$

$\begin{array}{llr}3.1 & \text { Objective } & 9\end{array}$

3.2 Results 9

$\begin{array}{ll}3.3 \text { Conclusion } & 9\end{array}$

$4 \quad$ Microbiological assessment $r$

5 Techno-economic analyses $\quad 14$

$6 \quad$ Sustainability analysis $\quad 16$

$\begin{array}{llr}7 & \text { Conclusions } & 18\end{array}$

$\begin{array}{lr}\text { Literature } & 20\end{array}$

$\begin{array}{lll}\text { Annex } 1 & \text { Techno-economic analyses } & 21\end{array}$ 


\section{Summary}

Brewers Spent Grain (BSG) is a side stream from beer production which is currently largely valorised for animal feed. Alternatively, it could also serve as a food ingredient; with an eye on nutritional value (relatively high content of dietary fibre and protein) it is considered a healthy food ingredients for western diets. Indigo / MaGie Creations is a start-up and intends to initiate the production of a food ingredient (first intended application: bread) from BSG. It creates additional value for the products in which this is added and it will reduce the food waste in Brewery and reduce use of grain for produce bread. With financial support of a Voucher from the Ministry of Agriculture, Nature and Food Quality a project was started to select the possible ways of collecting the BSG, to select a drying technology, to investigate the food safety of the process of collecting and drying, to analyse if the process is economically feasible and carry out an analysis on sustainability.

After the technological options and effects on microbiological and economic feasibility and sustainability effects have been investigated for the use of BSG as an application as an ingredient in food, it is concluded that it is quite possible under certain conditions. Those are collection on a foodsafe method, transport and process it either warm above $60^{\circ} \mathrm{C}$ of chill it rapidly before transport, remove water via a press, dry with a paddle or flash dryer and milling after drying to achieve an ingredient which can be used easily.

In sustainability analysis it was found that replacing wheat flour by dried BSG does contribute to net GHG emission reduction in food production, although the net saving is small compared to the total emissions. It also contributes to reduction of land use: using $1 \mathrm{~kg} \mathrm{BSG}$ as food ingredient, replacing $1 \mathrm{~kg}$ wholemeal flour, will free up $2 \mathrm{~m} 2$ farm land. 


\section{Introduction}

Brewers Spent Grain, BSG, is a side stream from beer production which is currently largely valorised for animal feed. Alternatively, it could also serve as a food ingredient; with an eye on nutritional value (relatively high content of dietary fibre and protein) it is considered a healthy food ingredients for western diets.

Indigo / MaGie Creations intends to set up the processing and commercialisation of brewers spent grain (BSG) as a shelf-stable food ingredient. This plan (supported by 'The Hague's agenda for a circular economy') is described in a report 'Circulair Den Haag - Haags Bierbostel'. In line with this plan, Indigo / MaGie Creations intends to dry fresh BSG to a shelf-stable food ingredient.

Data on macro-nutritional composition and total microbial count for a wet and dry sample are available.

Wageningen Food \& Biobased Research (WFBR) has plenty expertise on food processing technologies and their impact on the product, food processing side streams (like BSG), supply chain development, techno-economic assessment and sustainability analysis. These expertises are combined to explain effects of technology choices on technical, microbiological and economic feasibility and sustainability impact.

- $\quad$ Expert background knowledge and limited experiments were oriented on the following issues: choice of drying technology including:

- dryer technology selection, supported by a drying test at a supplier

- dryer dimensioning in relation to capacity, based on economic analysis

- recommendations on dryer type (taking into consideration material properties and sustainability) and estimate of drying energetic efficiency

- qualitative explanation of influence on product quality and/or nutritional value, with respect to stability and applicability in food

- microbial hazards and safety

- $\quad$ preservation of functionality and applicability of dried BSG (no physical determinations of functionality)

- $\quad$ scheme of the intended processing chain

- $\quad$ estimate of processing costs (OPEX and CAPEX) as function of processing volume, and including the distance between beer factory and BSG dryer

- $\quad$ estimate of GHG emission per kg dry material + comparison with replacement product in a typical application.

This report presents considerations on dryer selection Chapter 2; after that in Chapter 3 results of experimental work with a dryer and dried products are presented. Reflections on microbiological hazards are given in Chapter 4; techno-economic and greenhouse gas emissions analyses are presented in Chapters 5 and 6 respectively. Finally the findings are summarized in Chapter 7. 


\section{$2 \quad$ Drying}

Drying processes and thus drying equipment is available in a wide variety. Depending on the qualities of the product to dry and the demands on the dried product, a selection must be made. Because BSG tends to stick and cluster, a first selection was made for a paddle dryer; other options will be discussed in chapter 4 . It is good to realise that any dryer will be part of a process line that starts at extracting the BSG from the beer production process.

Because drying implies the evaporation of water, considerable energy uses are necessary for drying. Mechanical water removing, for instance by pressing or centrifuging the BSG, consumes far less energy and is therefore recommended as a process preceding the drying. BSG as it comes from the beer production is very wet and pressing to a much lower fluid/water content is well possible.

\section{$2.1 \quad$ Overview of dryers}

Drying processes and thus drying equipment is available in a wide variety. Depending on the qualities of the product to dry and the demands on the dried product, a selection must be made. Because BSG tends to stick and cluster, a first selection was made for a paddle dryer; other options will be discussed in chapter 4 . It is good to realise that any dryer will be part of a process line that starts at extracting the BSG from the beer production process.

Because drying implies the evaporation of water, considerable energy uses are necessary for drying. Mechanical water removing, for instance by pressing or centrifuging the BSG, consumes far less energy and is therefore recommended as a process preceding the drying. BSG as it comes from the beer production is very wet and pressing to a much lower fluid/water content is well possible.

\subsubsection{The Andritz paddle dryer}

In advance a paddle dryer is selected as being appropriate for drying of BSG. Andritz Gouda offers experiments at a pilot dryer; see the report of the experiments in Appendix 1. In advance there was doubt about the maximum temperature the BSG could tolerate before deterioration of the quality occurs, for instance browning or the formation of off tastes. From literature an upper limit of $60^{\circ} \mathrm{C}$ is known. Although the driving force for the drying comes from $3 \operatorname{bar}(\mathrm{g})$ steam, $140^{\circ} \mathrm{C}$, and the measured product temperature rises up to $100^{\circ} \mathrm{C}$, no visual or sensory deterioration of the quality could be ascertained. Testing of this product by skilled cooks will give a final judgement on the quality and applicability.

After drying the BSG still has the original sizes; it contains the hulls of grains / barley. These large 'fibres' tend to stick between teeth and are therefore less favourable for application in human food. The dried BSG is therefore milled in a laboratory grinder, type IKA, with sieves with 2 and $0.5 \mathrm{~mm}$ outgoing diameter. These milled BSG samples are applied for testing applications.

\subsubsection{Alternative dryers}

Test at pilot scale showed that the (Andritz) paddle dryer satisfies. Other suppliers also deliver paddle dryers. Alternative dryers should be considered especially with respect to the economy of the BSG reuse.

An alternative that is expected to satisfy as well is the flash dryer, the so called DMR offered by Hosokawa; see Figure 1 for its working principle. The incoming product is torn apart an partly milled by a rotating milling plate at the bottom of the drying chamber and the final dried product is selected before exhaust by a classifier. Test have not been performed but proper operation is expected, although no defined diameter is expected of the dried BSG from this process, thus a separate milling step may be necessary. 


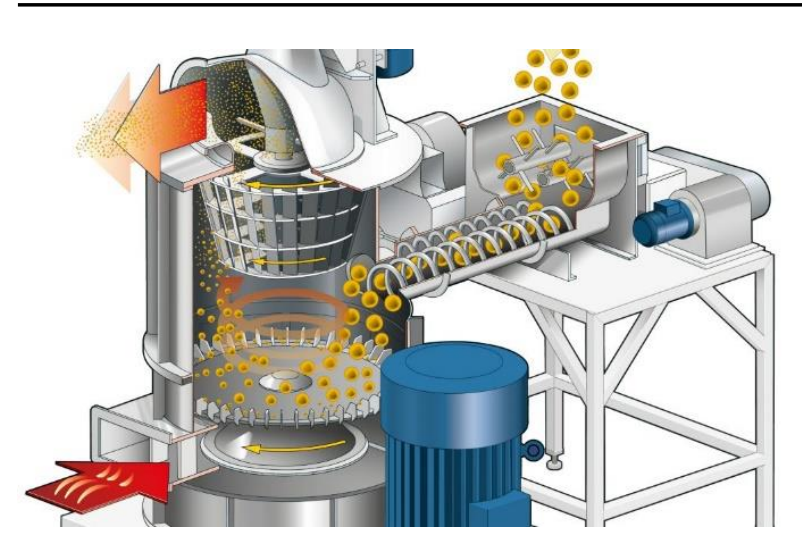

\section{Figure 1. Hosakawa DMR dryer working principle}

For any alternative dryer lump formation, that can occur with BSG and will hinder drying, should always be considered.

In Table 1 an overview of dryer types, their expected fitness for BSG drying and an indicative cost estimate.

Table 1. Overview of dryer types

\begin{tabular}{|c|c|c|c|c|c|}
\hline $\begin{array}{l}\text { Type of } \\
\text { dryer }\end{array}$ & Efficiency & $\begin{array}{l}\text { Energy use } \\
\text { per kg water } \\
\text { evaporation }\end{array}$ & general & $\begin{array}{l}\text { Suitability for } \\
\text { BSG drying }\end{array}$ & $\begin{array}{l}\text { Costs / } \\
\text { economy }\end{array}$ \\
\hline & $(\%)$ & $(\mathrm{kJ} / \mathrm{kg})$ & & & (indication) \\
\hline Paddle dryer & $50-80$ & $4800-3000$ & & & expensive \\
\hline Belt dryer & $40-60$ & $6000-4000$ & $\begin{array}{l}\text { Simple, } \\
\text { robust }\end{array}$ & $\begin{array}{l}\text { Risk of lump } \\
\text { formation }\end{array}$ & cheap \\
\hline Tunnel dryer & $35-40$ & $6950-6000$ & $\begin{array}{l}\text { Simple, } \\
\text { robust }\end{array}$ & $\begin{array}{l}\text { High risk of } \\
\text { lump formation }\end{array}$ & - \\
\hline $\begin{array}{l}\text { Fluid bed } \\
\text { dryer }\end{array}$ & $40-80$ & $4000-3000$ & & $\begin{array}{l}\text { Risk of lump } \\
\text { formation }\end{array}$ & moderate \\
\hline Room dryer & $40-60$ & $6000-4000$ & $\begin{array}{l}\text { Simple, } \\
\text { robust }\end{array}$ & $\begin{array}{l}\text { Risk of lump } \\
\text { formation }\end{array}$ & $\begin{array}{l}\text { Batch wise, } \\
\text { much handling }\end{array}$ \\
\hline $\begin{array}{l}\text { Infra red } \\
\text { dryer }\end{array}$ & $30-60$ & $8000-4000$ & & $\begin{array}{l}\text { 1-sided drying. } \\
\text { Risk of burning }\end{array}$ & moderate \\
\hline $\begin{array}{l}\text { Dielectric } \\
\text { dryer }\end{array}$ & $60^{1}$ & 4000 & & & expensive \\
\hline $\begin{array}{l}\text { Super Heated } \\
\text { Steam dryer }\end{array}$ & $\begin{array}{l}>100 \% \\
\text { with energy } \\
\text { reuse }\end{array}$ & $1500-3500$ & $\begin{array}{l}\text { Limited } \\
\text { availability } \\
\text { and } \\
\text { experience }\end{array}$ & possible & expensive \\
\hline
\end{tabular}

For the final dryer selection the throughput, operating hours and operator demand is very crucial.

\subsection{Drying as part of a process line}

Figure 2 shows a schematic BSG process line including drying. 

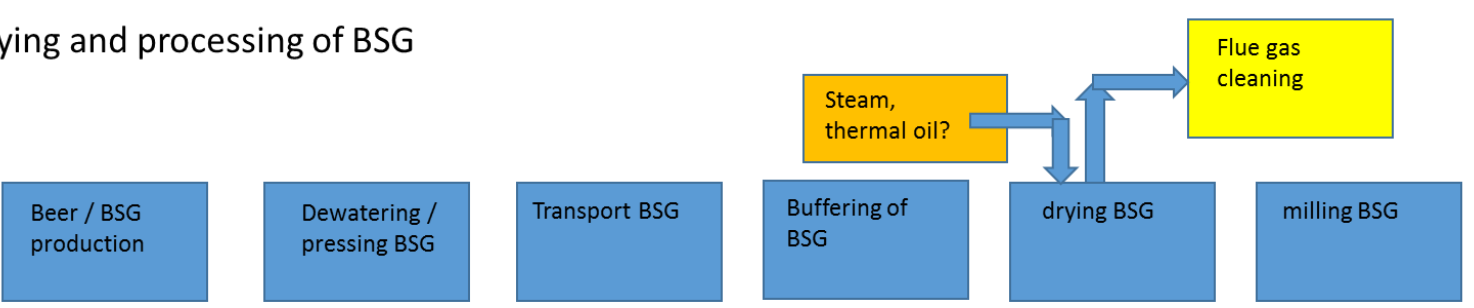

Figure 2. Processing line diagram for production of dried BSG powder from fresh BSG

Because of the perishability of BSG a direct coupling between the wort kettle at the brewery, where the BSG comes from, and the drying process line is strongly recommended. Because the BSG comes available periodically, a short in-between storage before entering the continuous drying process line will be necessary. As a mechanical dewatering is recommended, this can be installed before the storage making the stored BSG less heavy, voluminous and less perishable.

Laboratory tests on fresh BSG showed that pressing can reduce the moisture content from 75 to 43 to $31 \%$, depending on the pressure and pressing time. For industrial equipment the exact pressing efficiency must be determined.

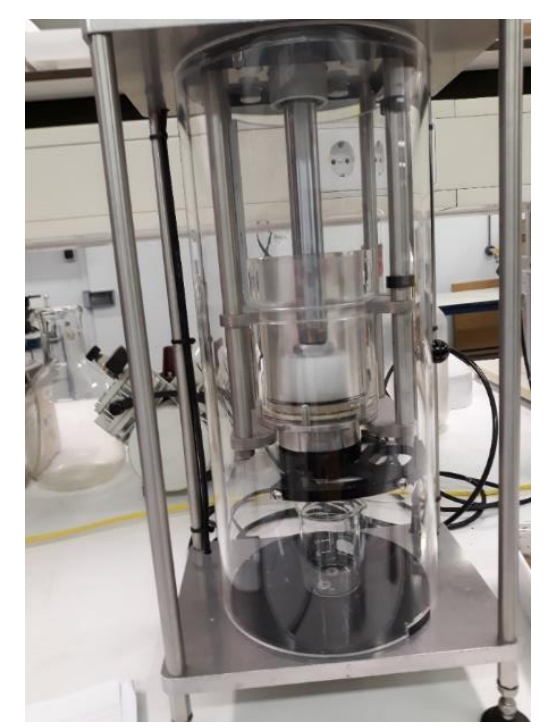

Figure 3 Laboratory pressing equipment

For dewatering/pressing electricity is needed, for drying electricity and a heat source like steam, thermal oil or electricity. These 'utilities' must be present.

A drying process will always have an exhaust to vent away the evaporated water to the environment. In principle exhaust gas cleaning is necessary because the exhaust air will contain dust and maybe some volatile smelling elements. The paddle dryer tests showed very little exhaust of dust from this drying process. A simple bag filter or wet scrubber is certainly appropriate (can also be used for the exhaust of the grinder). 


\section{Experiments with a paddle dryer}

Pilot test trials have been executed with the ANDRITZ Gouda Paddle Dryer 10 (GPD 10) with brewers spent grain. The aim was to achieve a more sustainable way to use the spent grain by making it suitable for human consumption. The BSG was supplied on the day preceding the tests and in this case the BSG originates from the Gulpener brewery located in Gulpen The Netherlands. The product was collected in plastic drums, transported in a refrigerated truck and kept refrigerated until the start of the test.

\subsection{Objective}

The objective of the tests was to reduce the residual moisture content from approximately $75 \%$ to 6 $2 \%$, preferably with the product temperature below the $70^{\circ} \mathrm{C}$.

\section{$3.2 \quad$ Results}

In the test, the product is being fed into the dryer continuously, while monitoring the temperature profile along the dryer length. This indicates the heating up curve of the product. A continuous mode test typically consists of three residence times, the first is used to fill the GPD using a calculated feed rate based on initial information like moisture content, bulk density and other product specific properties. The second residence time is used to stabilize the process in the GPD. The third residence time is used to confirm the process parameters and sample taking.

During the tests, the following data were collected:

- $\quad$ feed product parameters (moisture content, temperature, bulk density)

- $\quad$ end product parameters (residual moisture content, temperatures, appearance and colour, bulk density)

- $\quad$ process parameters (heating medium temperature / pressure, holdup inside the dryer)

- $\quad$ capacity of the product

The product has no plastic phase. There is slight encrustation visible in the beginning of the GPD but this is refreshed by new product. The product build-up does not pass $30 \%$ of the trough length. After 50 minutes, the dryer started to discharge the product and the product temperature at the outlet was $100^{\circ} \mathrm{C}$ and the product bed level is not stable. After 60 minutes the product bed is level and stable. After 180 minutes the test is stopped and samples are taken for moisture analysis. After deliberation with the customer is was decided to run the GPD with the same settings and produce additional sample material for the customer.

The customer tasted the dried product and approved the taste. There was some discoloration of the product.

The collection of surplus material came to an abrupt stop due to a foreign object blocking the GPD after 260 minutes.

Inspection of the paddles showed that there was slight encrustation visible in the first part of the GPD but this needed hardly any force to be removed.

\subsection{Conclusion}

Testing with the ANDRITZ Gouda Paddle dryer has proved that the product, Brewers spent grain, as tested at the ANDRITZ Gouda pilot plant located in Waddinxveen, provided by the customer is suitable for drying with the GPD technology.

The product provided by the customer can be dried with little to no taste degradation. 
The results with different spent grain samples can vary because these results are largely subject to variance in sugar content in the product.

The slight encrustation is refreshed by new product and is easily removed.

Using the data collected during the test the K-value is $188.7 \mathrm{~W} / \mathrm{m} 2 . \mathrm{K}$.

Temperatures exceeding $150^{\circ} \mathrm{C}$ have not been tested. If higher temperatures will result in increasing encrustation of the shafts and product taste degradation will have to be tested to conclude on. 


\section{Microbiological assessment}

In this paragraph, we describe the microbiological hazards of brewers spent grain (BSG), which is processed as soon as possible after release into a dehydrated product suitable for human consumption. We also describe which critical points during the production process are present. We assume the following aspects:

- Implementation of good manufacturing practices (GMP) and presence of HACCP

- Use of ingredients suitable for human food

- Heating of the final finished product for consumption (for example, the dehydrated beer grains are processed into bread that is still baked). Expert-judgement on preservation of functionality and applicability of dried BSG (no physical determinations of functionality)

Microbiological hazards of BSG spore-formers of pathogenic micro-organisms that survive the beer brewing process. Specifically, these include fungi and bacteria that can form spores, such as Fusarium spp., Aspergillus spp., Penicillium spp., Alternaria, Bacillus spp. (including Bacillus cereus) and Clostridium spp. (including Clostridium botulinum and Clostridium perfringens).

Intended process: the BSG coming from the brewer's chain will have a temperature of $80^{\circ} \mathrm{C}$ or higher and will be dehydrated as soon as possible.

By keeping the temperature of the brewing above $63^{\circ} \mathrm{C}$, pathogenic spores will not germinate and grow and thermophilic lactic acid bacteria cannot acidify the product. At temperatures of $63-70^{\circ} \mathrm{C}$, the non-pathogenic spores of Geobacillus stearothermophilus and Desulfotomaculum nigrificans may germinate and grow and possibly spoil the product. At slightly less high temperatures (57$62^{\circ} \mathrm{C}$ ), growth of Bacillus species (such as Bacillus amyloliquefaciens and Bacillus coagulans), Thermoanaerobacterium thermosaccharolyticum and thermophilic fungi can occur. At temperatures below $57^{\circ} \mathrm{C}$, growth of even more microorganisms, including pathogenic sporeformers [such as $B$. cereus (see Figure 4 below), C. botulinum, C. perfringens (see Figure 5) and toxin-producing fungi] may occur.

Critical points: The temperature of the BSG. Temperatures below $63^{\circ} \mathrm{C}$, but above $57^{\circ} \mathrm{C}$ are likely to be maintained for several hours. It is strongly advised not to let the temperature drop below $57^{\circ} \mathrm{C}$ due to possible growth of pathogenic micro-organisms. Temperatures of the grains below $57^{\circ} \mathrm{C}$ can therefore also be tolerated for a maximum of 2 hours, provided the BSG has been no longer than a few hours at temperatures between $63^{\circ} \mathrm{C}$ and $57^{\circ} \mathrm{C}$. Monitoring the temperature until the brew is dehydrated is essential.

To obtain a completely microbiologically stable dehydrated product at room temperature, the water activity $\left(a_{w}\right)$ should be 0.50 or less (to prevent the growth of xerophilic fungi). During storage, the product must be prevented from absorbing moisture.

Note: if the dehydrated product does not undergo further heat treatment, contamination by micro-organisms (such as pathogenic viruses, Salmonella spp. and Listeria monocytogenes) must be prevented. 
\begin{tabular}{l|l|} 
Init. level & 3 \\
\cline { 2 - 2 } Phys.state & 1 \\
\cline { 2 - 2 } Temp $\left({ }^{\circ} \mathrm{C}\right)$ & 34.00 \\
\hline pH & 7 \\
\hline Aw & 0.997 \\
\end{tabular}
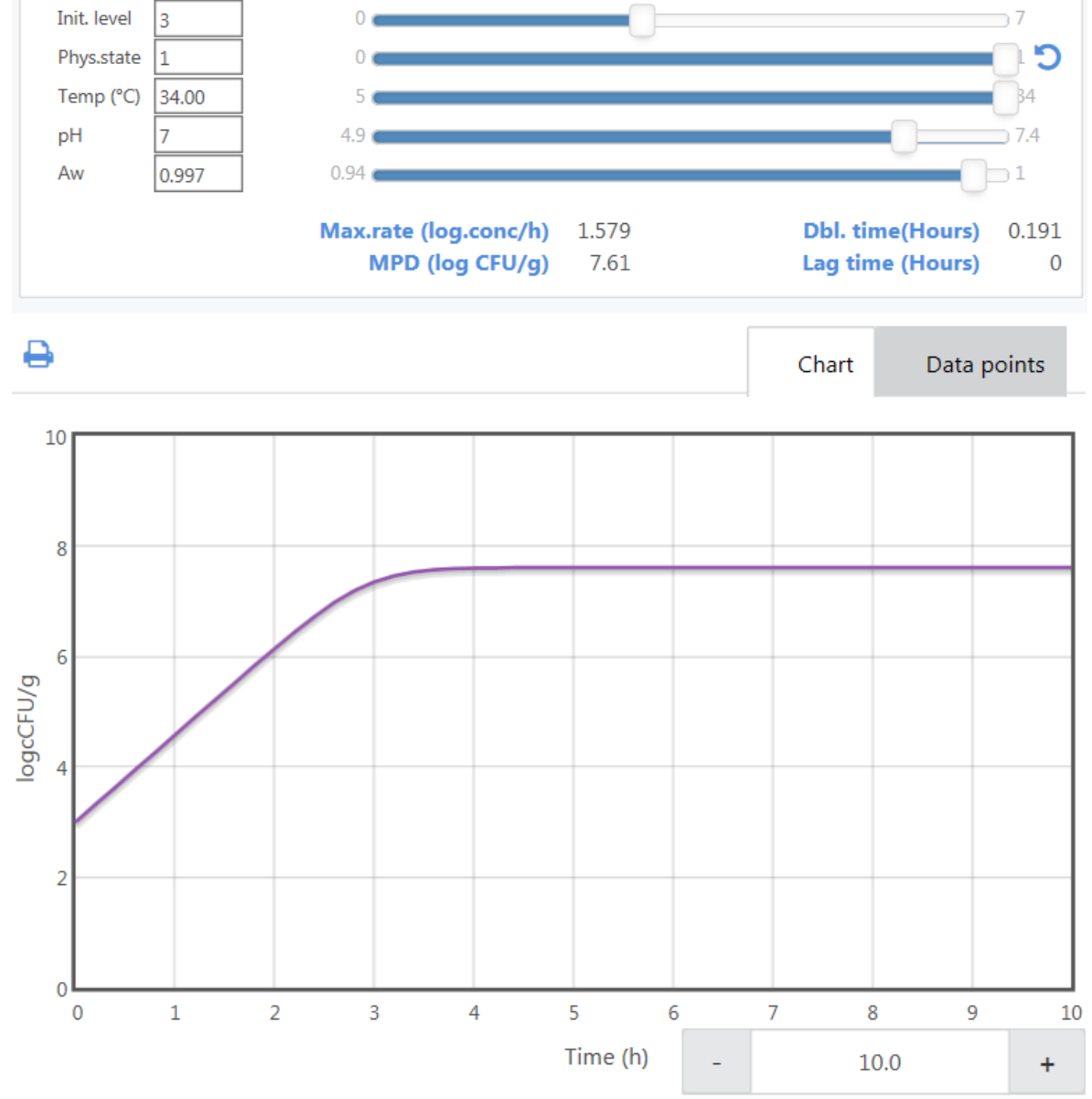

Figure 4. Predicted growth of Bacillus cereus at $34^{\circ} \mathrm{C}$ (optimum growth temperature and maximum temperature use for modelling ) in liquid medium, enriched with nutrients Source: ComBase (modulated on 10 juli 2019) 
Init. level

Phys.state

Temp $\left({ }^{\circ} \mathrm{C}\right)$

$\mathrm{pH}$

Aw

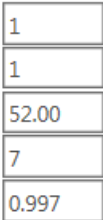

Max.rate (log.conc/h) 0.835

MPD (log CFU/g) 7.61

Dbl. time(Hours)

Lag time (Hours)
믐
Chart
Data points
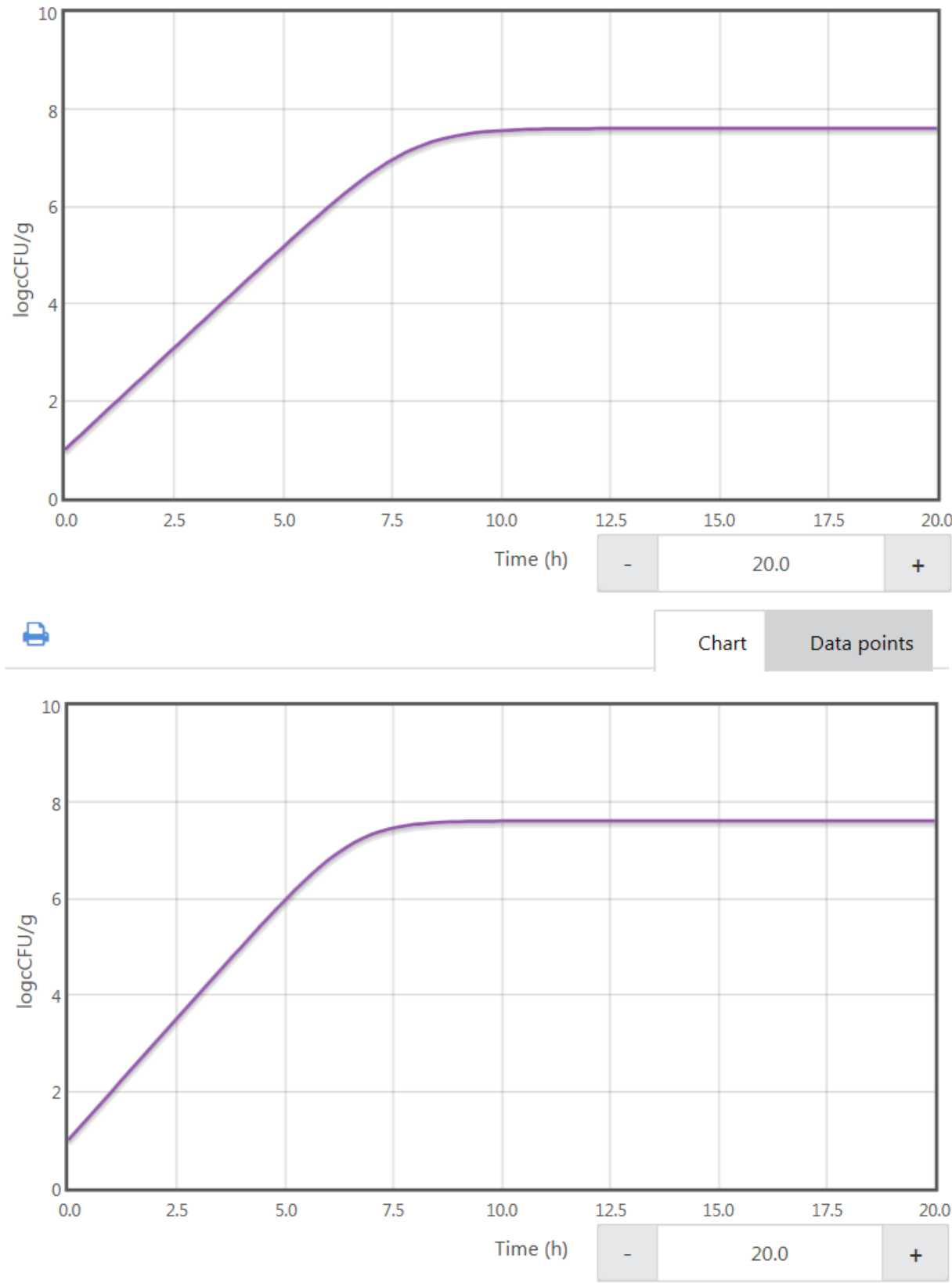

Figure 5. Predicted growth of Clostridium perfringens at $52^{\circ} \mathrm{C}$ (maximum temperature to model, upper graph) and $45^{\circ} \mathrm{C}$ (optimum growht temperature, lower graph) in liquid medium, enriched with nutrients. Source: ComBase (modulated on 10 juli 2019) 


\section{Techno-economic analyses}

To estimate the production costs of using BSG for food application the operational expenditure (OPEX) and capital expenditure (CAPEX, aka fixed capital) were determined based on the results of the experiments carried out with the paddle mixer and estimations of purchase and selling the BSG. The approach is shown in Figure 6.

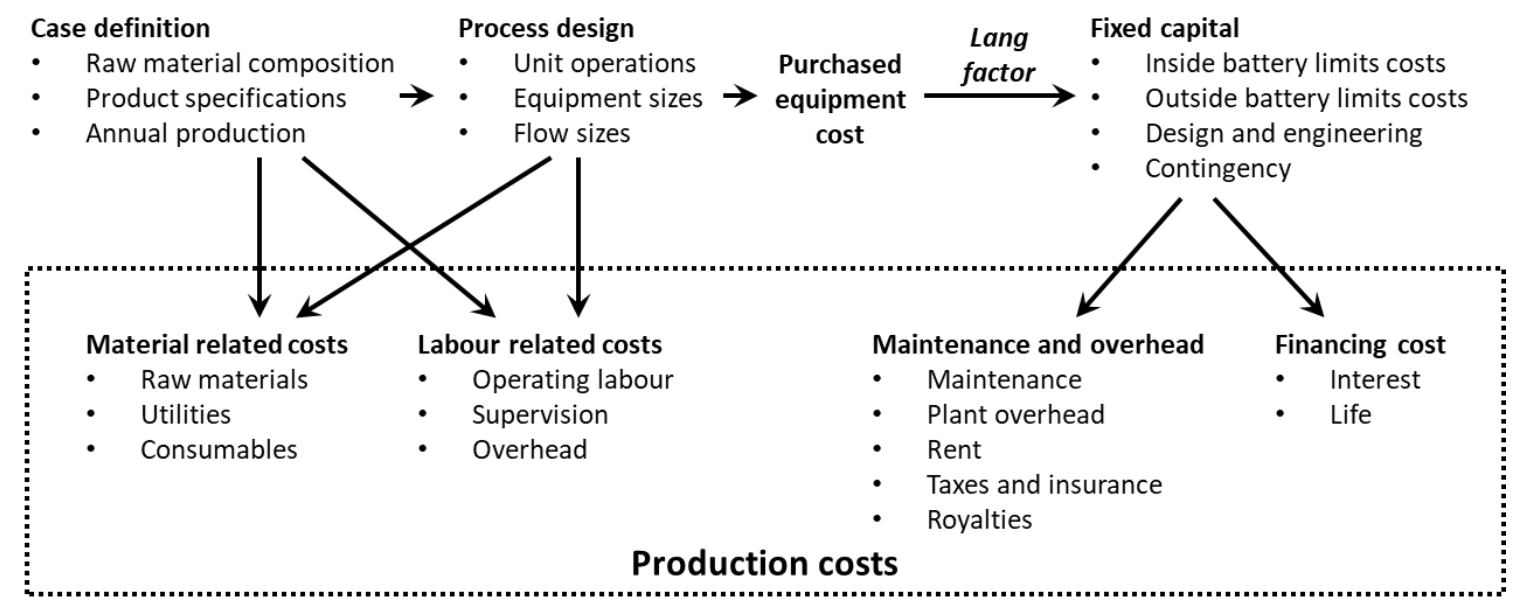

Figure 6 Approach of estimating the production costs

Two different scenarios are analysed: one without a press, and one with a press to remove a part of the moisture which is present in the BSG. The press increases the dry weight from $22 \%$ to $36 \%$, approximately half of the moisture is removed by the press. The press increases the purchased equipment and CAPEX.

The estimated production costs are used to calculate the economic indicators: average cash flow, simple pay-back period, net present value (NPV), and internal rate of return (IRR). An interest rate of $2.1 \%$, a tax rate of $35 \%$, and the MACRS 5 years depreciation method are used in the calculation of the economic indicators. The used raw material costs are $€ 30 /$ ton BSG and the product price is estimated on $€ 0.85 / \mathrm{kg}$ dried spent grain. All assumptions of the techno-economic analyses are given in Annex 1. An overview of the techno-economic evaluation is given in Table 2. The economic indicators are after tax and based on a 10 year period. 
Table 2. Overview of TEA

\begin{tabular}{lc|cc}
\hline & & without press & with press \\
\hline Spent Grain & $(\mathrm{kg} / \mathrm{h})$ & 3850 & 6311 \\
& $(\mathrm{ton} / \mathrm{y})$ & 30800 & 50492 \\
& $(\% \mathrm{DW})$ & $22 \%$ & $22 \%$ \\
\hline Pressed Spent Grain & $(\mathrm{kg} / \mathrm{h})$ & & 3850 \\
& $(\mathrm{ton} / \mathrm{y})$ & & 30800 \\
& $(\% \mathrm{DW})$ & & $36 \%$ \\
\hline Dried Spent Grain & $(\mathrm{kg} / \mathrm{h})$ & 892 & 1462 \\
& $(\mathrm{ton} / \mathrm{y})$ & 7133 & 11693 \\
& $(\% \mathrm{DW})$ & $95 \%$ & $95 \%$ \\
\hline Purchased equipment costs & $(\mathrm{k} €)$ & 1996 & 2328 \\
Capital expenditure & $(\mathrm{k} €)$ & 7982 & 9313 \\
\hline Main product revenue & $(\mathrm{k} € / \mathrm{y})$ & 6063 & 9939 \\
\hline Raw material costs & $(\mathrm{k} € / \mathrm{y})$ & 924 & 1515 \\
Utility costs & $(\mathrm{k} € / \mathrm{y})$ & 881 & 733 \\
Labour reated costs & $(\mathrm{k} € / \mathrm{y})$ & 446 & 446 \\
Maintenance and overhead & $(\mathrm{k} € / \mathrm{y})$ & 798 & 931 \\
\hline Cash COP & $(\mathrm{k} € / \mathrm{y})$ & 3049 & 3625 \\
\hline Average cash flow & $(\mathrm{k} € / \mathrm{yr})$ & 2344 & 4651 \\
Simple pay-back period & $(\mathrm{y})$ & 3.4 & 2.0 \\
Net present value & $(\mathrm{k} €)$ & 13139 & 32541 \\
Internal rate of return & $(\%)$ & $30 \%$ & $56 \%$ \\
\hline & & &
\end{tabular}

Because of the relatively large revenue (i.e. high product price), both scenarios are profitable. The scenario with press is significantly more profitable compared to the scenario without press, because of the larger production capacity. 


\section{$6 \quad$ Sustainability analysis}

In sustainability we compare the option of using BSG in bread to the reference situation (application for feed). The following effects should be adequately taken into consideration:

- When diverting BSG from animal feed to food application, the animal feed demand must be filled in through an alternative biomass. Since feeding value of BSG is largely based on the protein content, in the analysis we choose an obvious protein source for that: soy bean meal.

- The BSG derived food ingredient replaces wheat flour in the food application.

- No transport from the brewery to the dryer.

- Drying energy use: $1.3 \mathrm{~kg}$ steam per $\mathrm{kg}$ water removed.

- Press energy use is small compared to the steam use, and therefore neglected.

\section{GHG emissions analysis}

Parameters used in the calculations:

- GHG emissions attributed to $1 \mathrm{~kg}$ soy bean meal: in literature values varying from $0.4 \mathrm{~kg}$ (Mogensen, 2011), $0.5 \mathrm{~kg}$ (Zgola et al., 2016), 0.7kg (Cerri et al., 2017; Dalgaard et al., 2008) are found (all excluding post-harvest transport; differences due to region of sourcing, and whether or not to include land-use-change effects in consideration). Transport to Europe may add up to $0.4 \mathrm{~kg}$ CO2-eq. per $\mathrm{kg}$ soy bean meal. We choose a typical value: $0.9 \mathrm{~kg} \mathrm{CO2-}$ eq. per kg soybean meal (agricultural production + ocean transport).

- Replacement ratio in feed (based on protein content): $2: 1$ (soybean meal: $0.47 \mathrm{~kg}$ protein $/ \mathrm{kg}$; BSG: $0.285 \mathrm{~kg}$ protein $/ \mathrm{kg}$, based on CVB Veevoedertabel)

- GHG emissions attributed to $1 \mathrm{~kg}$ wheat flour: $0.77 \mathrm{~kg}$ CO2-eq. per $\mathrm{kg}$ flour (see Appendix).

- GHG emissions steam generation $0.166 \mathrm{~kg} \mathrm{CO} 2$ eq. per kg steam.

Net result of upgrading $1 \mathrm{~kg} \mathrm{BSG}$ to food (dry product basis):

- requires $0.5 \mathrm{~kg}$ soybean meal in feed: $+0.45 \mathrm{~kg}$ CO2-eq.

- requires evaporation of about $1 \mathrm{~kg}$ water: $+0.22 \mathrm{~kg} \mathrm{CO} 2-\mathrm{eq}$.

- prevents use of $1 \mathrm{~kg}$ wheat flour: $-0.77 \mathrm{~kg} \mathrm{CO2-eq.}$

Result: net reduction of $0.10 \mathrm{~kg} \mathrm{CO}$-eq per $\mathrm{kg} \mathrm{BSG}$ food ingredient.

It is concluded that replacing wheat flour by dried BSG does also contribute to net GHG emission reduction in food production, although the net saving is small compared to the total emissions.

\section{Analysis of effect on land use}

Analysing impact on land use is more fuzzy than GHG emission effects calculation. This is due to the fact that replacement products (see above) are derived from different continents: when transferring usage as feed to bread ingredient, wheat which is mostly derived from Europe would be replaced by soy from another continent. There's one country that we import both products from in substantial volumes: the USA. Therefore we use production yields from USA, based on FAOSTAT (http://www.fao.org/faostat/en/\#data/QC, average for 2016 and 2017):

- soybeans: 3.4 ton per hectare, that is $0.34 \mathrm{~kg}$ per $\mathrm{m}^{2}$.

- wheat: 3.3 ton per hectare, that is $0.33 \mathrm{~kg}$ per $\mathrm{m}^{2}$.

Like in full LCA we use a price-allocation to indicate land use to soybean meal (the beans are separated in oil and meal). Rules of thumb: the total oil value is equal to the value of the meal; $1 \mathrm{~kg}$ bean gives $0.73 \mathrm{~kg}$ meal (https://odells.typepad.com/blog/an-explanation-of-the-soybean-crush.html).

Calculation of land use change due to extracting $1 \mathrm{~kg}$ BSG from feed:

- Replacement product: soybean meal, volume: $0.5 \mathrm{~kg}$ (see above).

- Meal to beans ratio is $0.73: 1.00$. Thus for $0.5 \mathrm{~kg}$ meal $0.5 / 0.73=0.68 \mathrm{~kg}$ soybeans are needed.

- Only half of soybean value is allocated to the meal; the other half is allocated to oil. Thus, half of 0.68 , that is $0.34 \mathrm{~kg}$, soybeans are allocated to the feed demand.

- $0.34 \mathrm{~kg}$ soybean is produced on $1 \mathrm{~m}^{2}$. 
Thus, when $1 \mathrm{~kg}$ BSG is used as bread ingredient instead of traditional use in feed, $1 \mathrm{~m}^{2}$ land extra is needed for the replacing soybean meal.

Calculation of land use change due to preventing wheat in bread related to $1 \mathrm{~kg}$ BSG:

- Replacement product: wholemeal wheat flour, volume: $1 \mathrm{~kg}$ (see above).

- wholemeal flour: wheat ratio is $1: 1$

- $1 \mathrm{~kg}$ wheat is produced on $3 \mathrm{~m}^{2}$.

Thus, when $1 \mathrm{~kg}$ BSG is used as bread ingredient instead of traditional use in feed, $3 \mathrm{~m}^{2}$ less land is needed for the growing the traditional ingredient wheat.

Net result: use of $1 \mathrm{~kg}$ BSG as food ingredient, replacing $1 \mathrm{~kg}$ wholemeal flour, will free up $2 \mathrm{~m}^{2}$ farm land.

\section{Effect on nitrogen emissions to air}

The Dutch government and agricultural sector aims to reduce nitrogen emissions from livestock through reducing nitrogen (mainly in proteins) content of feed. It is expected that especially proteinrich feed ingredients will be reduced; BSG only has moderate protein content, so we do not foresee a change in market attitude. It could become more attractive from this perspective, but this is still unclear. 


\section{$7 \quad$ Conclusions}

In previous chapters technology options and effects on microbiological and economic feasibility and sustainability impact were presented. An integrated summary of the findings and recommendations:

- Compositional/microbial analyses of a few fresh samples has shown that these fresh products are food-safe, and when they sufficiently soon are treated through an adequate preservation treatment will result in a food-grade product.

- $\quad$ Storage (possibly in transport) for fresh material: Microbial growth reaches a maximum around $40^{\circ} \mathrm{C}$. Hence, occurrence of such temperatures should be minimised. This can be achieved by either direct further processing, rapid cooling to low temperature regime or keeping high product temperature (preferably above $60^{\circ} \mathrm{C}$ ). (In the current animal feed chains, the product's pH is reduced - through auto-fermentation or acidification - to make it stable at ambient temperatures; this option is not preferred for food application because it may affect product perception).

- Pre-processing: Through pressing, a significant amount of water can be removed from the product (typically $50 \%$ ). This step is relatively inexpensive, though may still be relevant because of required investments; energy use is low compared to the alternative of evaporating the water.

Disadvantage: the removed water fraction will contain some solids. This is a loss of material, and disposal as waste water will give to some additional costs.

- Drying: In the selection process of adequate drying process, specifically stickiness and lumping behaviour of the material is largely limiting the set of suitable technologies. Paddle and flash driers are considered suitable. From these, a paddle dryer was selected because of anticipated cost-benefit ratio.

At temperatures above $60^{\circ} \mathrm{C}$ possibly the product is vulnerable to browning reactions and offflavour development. However, in pilot tests, where temperatures up to $100^{\circ} \mathrm{C}$ occurred, these effects were not detected in the final produce.

- Milling: After flash drying the milling degree can be adapted to the final customer's preference. The paddle-dried product can be milled to any desired powder size (in contrary to flash drying that results in less defined or controllable particle sizes).

- In the spatial design of the processing chain principles of food safety, economies of scale and efficiency should be taken into consideration. This leads to the following recommendations:

- Minimise the time between production and processing of the BSG.

- However, with an eye on the common brewing process practice, fresh BSG will be generated batch-wise. Adequate storage conditions (see above) is recommended. Depending on the volumes and efficiency of transport, this storage may be either at the brewery or drying factory.

- Economies of scale are small for pressing; with an eye on transport efficiency we recommend to consider applying this step at the beer brewery (thus prior to transport).

- $\quad$ Drying processes are generally more sensitive to economies of scale; hence we recommend drying at one centralised location.

- $\quad$ Transporting (either or not pre-processed) BSG to the central drying factory will have a significant effect on total cost price. Thus, notwithstanding previous points, it would be relevant to choose a beer factory that could fulfil all BSG input needs, so that the transportation step can be skipped.

- Sustainability: effects of replacing wheat by BSG in bread were analysed:

- $\quad$ Replacing wheat flour by dried BSG does contribute to net GHG emission reduction in food production, although the net saving is small compared to the total emissions. 
- Using $1 \mathrm{~kg}$ BSG as food ingredient, replacing $1 \mathrm{~kg}$ wholemeal flour, will free up $2 \mathrm{~m}^{2}$ farm land.

\section{Estimates of volumes}

Production of BSG in The Netherlands is estimated at 500 kton per year; thus the biggest breweries are estimated to produce at least $100 \mathrm{kton} /$ year.

When aiming for 7 ton per year dry BSG product, only about 30kton BSG (wet basis) is needed, which certainly can be supplied by one medium to large-scale brewery. 


\section{Literature}

Microbiological assessment

- $\quad$ NVWA infobladen over sporenvormende bacteriële voedselpathogenen (Bacillus cereus, Bacillus subtilis, Bacillus licheniformis, Clostridium botulinum en Clostridium perfringens).

- De Loy-Hendrickx Anja, Debevere Johan, Devlieghere Frank, Jacxsens Liesbeth, Uyttendaele Mieke, Vermeulen An. Microbiological Guidelines: Support for Interpretation of Microbiological Test Results of Foods, Chapter 3: Food-borne pathogens. Editor: Uyttendaele Mieke. 2018.

- Jose M. Lorenzo, Paulo E. Munekata, Ruben Dominguez, Mirian Pateiro, Jorge A. Saraiva, Daniel Franco. Main Groups of Microorganisms of Relevance for Food Safety and Stability: General Aspects and Overall Description. In: Editor(s): Francisco J. Barba, Anderson S. Sant'Ana, Vibeke Orlien, Mohamed Koubaa. Innovative Technologies for Food Preservation, 2018, https://doi.org/10.1016/B978-0-12-811031-7.00003-0.

- Carlin, Frederic; Albagnac, Christine; Rida, Ammar; Guinbretiere, Marie-Helene; Couvert, Olivier; and Nguyen-the, Christophe; Variation of cardinal growth parameters and growth limits according to phylogenetic affiliation of the Bacillus Cereus Group. Consequences for risk assessment. Food Microbiology 33 (2013) 69-76.

- $\quad$ Ramesh Maheshwari, Girish Bharadwaj, Mahalingeshwara K. Bhat. Thermophilic Fungi: Their Physiology and Enzymes. Microbiol. Mol. Biol. Rev. Sep 2000, 64 (3) 461-488; DOI: 10.1128/MMBR.64.3.461-488.2000.

- Visser, M., Parshina, S. N., Alves, J. I., Sousa, D. Z., Pereira, I. A. C., Muyzer, G., ... Stams, A. J. M. (2014). Genome analyses of the carboxydotrophic sulfate-reducers Desulfotomaculum nigrificans and Desulfotomaculum carboxydivorans and reclassification of Desulfotomaculum caboxydivorans as a later synonym of Desulfotomaculum nigrificans. Standards in Genomic Sciences, 9(3), 655-675. https://doi.org/10.4056/sigs.4718645.

- T. Deák, Food Technologies: Sterilization, In: Encyclopedia of Food Safety, 2014, https://doi.org/10.1016/B978-0-12-378612-8.00258-4.

GHG analysis

Cerri C.E.P., X. You, M.R. Cherubin, C.S. Moreira, G.S. Raucci, B. de Almeida Castigioni, P.A. Alves, D.G.P. Cerri, F.F. de Castro Mello \& C.C. Cerri (2017): Assessing the greenhouse gas emissions of Brazilian soybean biodiesel production. PLoS ONE. 12(5): e0176948.

Dalgaard, R, Schmidt, J., Halberg, N., Christensen, P., Thrane, M., Pengue, W. A. (2008): LCA of soybean meal. Int. J. LCA. 13:240-254

Davis, J. \& U. Sonesson (2008): Environmental potential of grain legumes in meals. Life cycle assessment of meals with varying content of peas, SIK, The Swedish Institute for Food and Biotechnology, report $\mathrm{Nr} 771$.

Mogensen, L. (2011): Greenhouse gas emissions from feed production, https://pure.au.dk/portal/files/44291895/LIM_Greenhouse_gas_emissions_from_feed_paper. pdf (accessed 24 April 2019).

Zgola, M., J. Reinhard, X. Liao et al. (2016): Update of Soybean Life Cycle Analysis, Report, Quantis, for United Soybean Board, https://unitedsoybean.org/wpcontent/uploads/Quantis_USB_SoybeanLCA_FinalReport_trunc_20160825.pdf (accessed 24 April 2019). 


\section{Annex 1 Techno-economic analyses}

\subsection{Scenario without press}

\subsubsection{Production costs}

\begin{tabular}{|c|c|}
\hline Operating hours & $8000 \mathrm{~h} / \mathrm{yr}$ \\
\hline \multirow[t]{3}{*}{ Spent Grain } & $3850 \mathrm{~kg} / \mathrm{h}$ \\
\hline & 30800 ton/y \\
\hline & $22 \% \mathrm{DW}$ \\
\hline \multirow[t]{3}{*}{ Dried Spent Grain } & $892 \mathrm{~kg} / \mathrm{h}$ \\
\hline & 7133 ton/y \\
\hline & $95 \% \mathrm{DW}$ \\
\hline \multicolumn{2}{|l|}{ Raw material costs } \\
\hline Brewers Spent Grain & $30 € /$ ton \\
\hline \multicolumn{2}{|l|}{ Utility costs } \\
\hline Electricity & $0.08 € / \mathrm{kWh}$ \\
\hline Steam & $25 € /$ ton st. \\
\hline Operating labour & $100 \%$ \\
\hline Supervision & $25 \%$ \\
\hline Direct salary overhead & $63 \%$ \\
\hline General plant overhead & $122 \%$ \\
\hline Labour related costs & $309 \%$ \\
\hline Shift positions & 1 \\
\hline Operators per shift position & 4.8 \\
\hline \multirow[t]{2}{*}{ Operating labour costs } & $18 € /($ operator $\cdot h)$ \\
\hline & $30 \mathrm{k} € /($ operator $\cdot \mathrm{y})$ \\
\hline Labour related costs & $446 \mathrm{k} € / \mathrm{y}$ \\
\hline Lang factor (grass roots) & 4.0 FC/PEC \\
\hline Plant related costs & $10 \%$ of $\mathrm{FC} / \mathrm{y}$ \\
\hline Financing costs & $10 \%$ of $\mathrm{FC} / \mathrm{y}$ \\
\hline
\end{tabular}

\begin{tabular}{lc}
\hline Budget Quotation Andritz & \\
Paddle dryer (GPD 17W300) & $1663 \mathrm{k€}$ \\
Purchased equipment costs (PEC) & $1.3 \mathrm{~kg} / \mathrm{kg}$ w.r. \\
Specific steam consumption & $175 \mathrm{~kW}$ \\
Electrical power installed & \\
\hline \multicolumn{2}{l}{} \\
\hline Other assumptions \\
PEC buffer vessel, press, and grinder & $20 \%$ of dryer \\
\hline
\end{tabular}

\begin{tabular}{ll}
\hline PEC & $2.0 \mathrm{M} €$ \\
Fixed capital & $8.0 \mathrm{M} €$ \\
\hline & \\
\hline Processing costs & $924 \mathrm{k} € / \mathrm{y}$ \\
\hline Raw material & $769 \mathrm{k} / \mathrm{y}$ \\
Steam & $112 \mathrm{k} € / \mathrm{y}$ \\
Electricity & $446 \mathrm{k} / \mathrm{y}$ \\
Labour related & $798 \mathrm{k} / \mathrm{y}$ \\
Plant related & $798 \mathrm{k} / \mathrm{y}$ \\
Financing & $3847 \mathrm{k} / \mathrm{y}$ \\
\hline Total & $0.13 € / \mathrm{kg}$ product \\
\hline Raw material & $0.11 € / \mathrm{kg}$ product \\
Steam & $0.02 € / \mathrm{kg}$ product \\
Electricity & $0.06 € / \mathrm{kg}$ product \\
Labour related & $0.11 € / \mathrm{kg}$ product \\
Plant related & $0.11 € / \mathrm{kg}$ product \\
Financing & $0.54 € / \mathrm{kg}$ product \\
\hline Total &
\end{tabular}

\subsubsection{Internal rate of return and net present value}

\begin{tabular}{l|ccccccccccc}
\hline & $\mathrm{k} € / \mathrm{yr}$ & & & & & & & & & & \\
Project year & 0 & 1 & 2 & 3 & 4 & 5 & 6 & 7 & 8 & 9 & 10 \\
\hline Capital expenditure & 7982 & & & & & & & & & & \\
Revenue & & 6063 & 6063 & 6063 & 6063 & 6063 & 6063 & 6063 & 6063 & 6063 & 6063 \\
Cash cost of production & & 3049 & 3049 & 3049 & 3049 & 3049 & 3049 & 3049 & 3049 & 3049 & 3049 \\
Gross profit & & 3014 & 3014 & 3014 & 3014 & 3014 & 3014 & 3014 & 3014 & 3014 & 3014 \\
Depreciation charge & & 1596 & 2554 & 1533 & 920 & 920 & 460 & 0 & 0 & 0 & 0 \\
Taxable income & & 1417 & 459 & 1481 & 2094 & 2094 & 2554 & 3014 & 3014 & 3014 & 3014 \\
Taxes paid & & 0 & 496 & 161 & 518 & 733 & 733 & 894 & 1055 & 1055 & 1055 \\
Cash Flow & -7982 & 3014 & 2518 & 2853 & 2495 & 2281 & 2281 & 2120 & 1959 & 1959 & 1959 \\
Discount factor & $100 \%$ & $98 \%$ & $96 \%$ & $94 \%$ & $92 \%$ & $90 \%$ & $88 \%$ & $86 \%$ & $85 \%$ & $83 \%$ & $81 \%$ \\
Present value of cash flow & -7982 & 2952 & 2415 & 2681 & 2296 & 2056 & 2013 & 1833 & 1659 & 1625 & 1591 \\
\hline Net present value (k€) & -7982 & -5031 & -2615 & 65 & 2362 & 4417 & 6431 & 8264 & 9922 & 11547 & 13139 \\
\hline
\end{tabular}




\subsection{Scenario with press}

\subsubsection{Production costs}

\begin{tabular}{lc}
\hline Operating hours & $8000 \mathrm{~h} / \mathrm{yr}$ \\
\hline Spent Grain & $6311 \mathrm{~kg} / \mathrm{h}$ \\
$50492 \mathrm{ton} / \mathrm{y}$ \\
$22 \% \mathrm{DW}$
\end{tabular}

\begin{tabular}{lc}
\hline Budget Quotation Andritz & \\
Paddle dryer (GPD 17W300) & $1663 \mathrm{k€}$ \\
Purchased equipment costs (PEC) & $1.3 \mathrm{~kg} / \mathrm{kg}$ w.r. \\
Specific steam consumption & $175 \mathrm{~kW}$ \\
Electrical power installed & \\
\hline \multicolumn{2}{l}{ Other assumptions } \\
PEC buffer vessel, press, and grinder & $40 \%$ of dryer \\
\hline
\end{tabular}

\begin{tabular}{lc}
\hline PEC & $2.3 \mathrm{M} €$ \\
Fixed capital & $9.3 \mathrm{M} €$ \\
\hline & \\
\hline Processing costs & $1515 \mathrm{k} € / \mathrm{y}$ \\
\hline Raw material & $621 \mathrm{k} € / \mathrm{y}$ \\
Steam & $112 \mathrm{k} / \mathrm{y}$ \\
Electricity & $446 \mathrm{k} / \mathrm{y}$ \\
Labour related & $931 \mathrm{k} / \mathrm{y}$ \\
Plant related & $931 \mathrm{k} € / \mathrm{y}$ \\
Financing & $4556 \mathrm{k} / \mathrm{y}$ \\
\hline Total & $0.13 € / \mathrm{kg}$ product \\
\hline Raw material & $0.05 € / \mathrm{kg}$ product \\
Steam & $0.01 € / \mathrm{kg}$ product \\
Electricity & $0.04 € / \mathrm{kg}$ product \\
Labour related & $0.08 € / \mathrm{kg}$ product \\
Plant related & $0.08 € / \mathrm{kg}$ product \\
Financing & $0.39 € / \mathrm{kg}$ product \\
\hline Total &
\end{tabular}

\subsubsection{Internal rate of return and net present value}

\begin{tabular}{l|ccccccccccc}
\hline & $\mathrm{k} € / \mathrm{yr}$ & & & & & & & & & & \\
Project year & 0 & 1 & 2 & 3 & 4 & 5 & 6 & 7 & 8 & 9 & 10 \\
\hline Capital expenditure & 9313 & & & & & & & & & & \\
Revenue & & 9939 & 9939 & 9939 & 9939 & 9939 & 9939 & 9939 & 9939 & 9939 & 9939 \\
Cash cost of production & & 3625 & 3625 & 3625 & 3625 & 3625 & 3625 & 3625 & 3625 & 3625 & 3625 \\
Gross profit & & 6314 & 6314 & 6314 & 6314 & 6314 & 6314 & 6314 & 6314 & 6314 & 6314 \\
Depreciation charge & & 1863 & 2980 & 1788 & 1073 & 1073 & 536 & 0 & 0 & 0 & 0 \\
Taxable income & & 4452 & 3334 & 4526 & 5242 & 5242 & 5778 & 6314 & 6314 & 6314 & 6314 \\
Taxes paid & & 0 & 1558 & 1167 & 1584 & 1835 & 1835 & 2022 & 2210 & 2210 & 2210 \\
Cash Flow & -9313 & 6314 & 4756 & 5147 & 4730 & 4480 & 4480 & 4292 & 4104 & 4104 & 4104 \\
Discount factor & $100 \%$ & $98 \%$ & $96 \%$ & $94 \%$ & $92 \%$ & $90 \%$ & $88 \%$ & $86 \%$ & $85 \%$ & $83 \%$ & $81 \%$ \\
Present value of cash flow & -9313 & 6185 & 4563 & 4836 & 4353 & 4038 & 3955 & 3711 & 3476 & 3404 & 3334 \\
\hline Net present value (k€) & -9313 & -3128 & 1434 & 6271 & 10623 & 14661 & 18616 & 22327 & 25802 & 29207 & 32541 \\
\hline
\end{tabular}





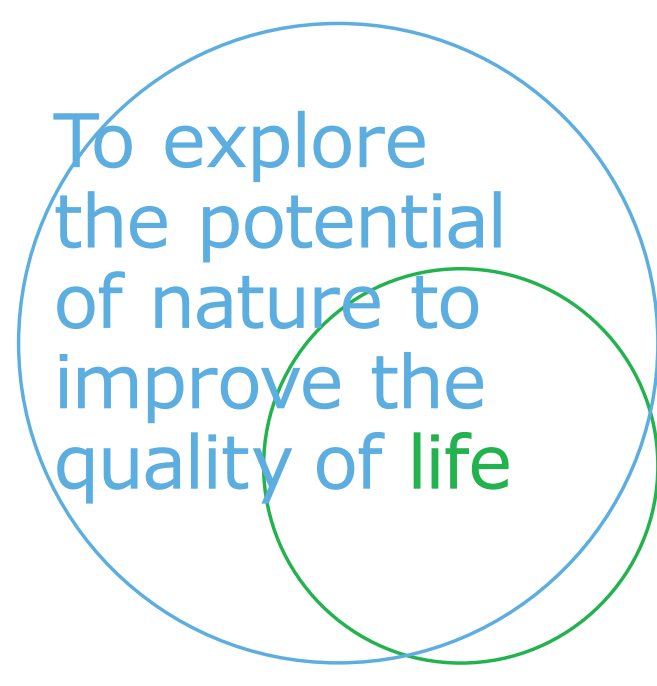

Wageningen Food \& Biobased Research Bornse Weilanden 9

6708 WG Wageningen

The Netherlands

www.wur.eu/wfbr

Einfo.wfbr@wur.nl

Report 2081

Confidential

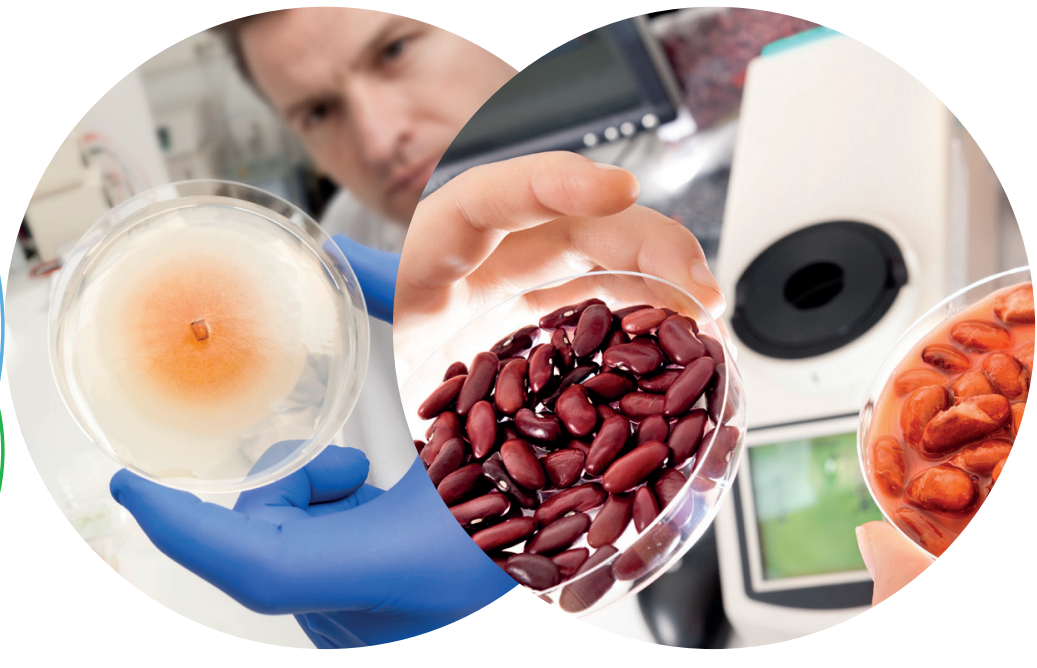

The mission of Wageningen University and Research is "To explore the potential of nature to improve the quality of life". Under the banner Wageningen University \& Research, Wageningen University and the specialised research institutes of the Wageningen Research Foundation have joined forces in contributing to finding solutions to important questions in the domain of healthy food and living environment. With its roughly 30 branches, 6,500 employees (5,500 fte) and 12,500 students, Wageningen University \& Research is one of the leading organisations in its domain. The unique Wageningen approach lies in its integrated approach to issues and the collaboration between different disciplines. 